\title{
Tsunami Source of the 2010 Mentawai, Indonesia Earthquake Inferred from Tsunami Field Survey and Waveform Modeling
}

\author{
Kenji Satake, ${ }^{1}$ Yuichi Nishimura, ${ }^{2}$ Purna Sulastya Putra, ${ }^{2,3}$ Aditya Riadi Gusman, ${ }^{2}$ Haris Sunendar, ${ }^{2}$ \\ Yushiro FujiI, ${ }^{4}$ Yuichiro Tanioka, ${ }^{2}$ Hamzah Latief, ${ }^{5}$ and Eko Yulianto ${ }^{3}$
}

\begin{abstract}
The 2010 Mentawai earthquake (magnitude 7.7) generated a destructive tsunami that caused more than 500 casualties in the Mentawai Islands, west of Sumatra, Indonesia. Seismological analyses indicate that this earthquake was an unusual "tsunami earthquake," which produces much larger tsunamis than expected from the seismic magnitude. We carried out a field survey to measure tsunami heights and inundation distances, an inversion of tsunami waveforms to estimate the slip distribution on the fault, and inundation modeling to compare the measured and simulated tsunami heights. The measured tsunami heights at eight locations on the west coasts of North and South Pagai Island ranged from 2.5 to $9.3 \mathrm{~m}$, but were mostly in the $4-7 \mathrm{~m}$ range. At three villages, the tsunami inundation extended more than $300 \mathrm{~m}$. Interviews of local residents indicated that the earthquake ground shaking was less intense than during previous large earthquakes and did not cause any damage. Inversion of tsunami waveforms recorded at nine coastal tide gauges, a nearby GPS buoy, and a DART station indicated a large slip (maximum $6.1 \mathrm{~m}$ ) on a shallower part of the fault near the trench axis, a distribution similar to other tsunami earthquakes. The total seismic moment estimated from tsunami waveform inversion was $1.0 \times 10^{21} \mathrm{Nm}$, which corresponded to $M_{w}$ 7.9. Computed coastal tsunami heights from this tsunami source model using linear equations are similar to the measured tsunami heights. The inundation heights computed by using detailed bathymetry and topography data and nonlinear equations including inundation were smaller than the measured
\end{abstract}

1 Earthquake Research Institute, University of Tokyo, 1-1-1 Yayoi, Bunkyo-ku, Tokyo 113-0032, Japan. E-mail: satake@eri.utokyo.ac.jp

2 Institute of Seismology and Volcanology, Hokkaido University, Kita 10 Nishi 8, Kita-ku, Sapporo 060-0810, Japan. E-mail: yns@mail.sci.hokudai.ac.jp; purna@mail.sci.hokudai.ac.jp; adit@mail.sci.hokudai.ac.jp; haris.sunendar34@gmail.com; tanioka@mail.sci.hokudai.ac.jp;

3 Research Center for Geotechnology, Indonesian Institute of Science, Jalan Cisitu, Bandung 40135, Indonesia. E-mail: ekoy001@yahoo.com

4 International Institute of Seismology and Earthquake Engineering, Building Research Institute, 1 Tachihara, Tsukuba, Ibaraki 305-0802, Japan. E-mail: fujii@kenken.go.jp

5 Department of Oceanography, Bandung Institute of Technology, Jalan Ganesha 10, Bandung 40132, Indonesia. E-mail: hamzahlatief1410@yahoo.co.id ones. This may have been partly due to the limited resolution and accuracy of publically available bathymetry and topography data. One-dimensional run-up computations using our surveyed topography profiles showed that the computed heights were roughly similar to the measured ones.

Key words: Tsunami, earthquake, Mentawai earthquake, Indonesia, Indian ocean.

\section{Introduction}

Off the west coast of Sumatra Island, Indonesia, subduction of the Indian Ocean Plate (Fig. 1) has produced several great interplate earthquakes such as the 26 December 2004 Sumatra-Andaman earthquake (M 9.1 according to the United States Geological Survey, USGS), the 28 March 2005 Nias earthquake (M 8.6), and the 12 September 2007 Bengkulu earthquakes (M 8.5 and 7.9; FujI and SAtake 2008; BORRERo et al., 2009). In the region of the Mentawai Islands, no great earthquake has occurred since 1797 and 1833 (Natawidjaja et al., 2006; Sieh et al., 2008); hence, the area is considered to be a seismic gap. The 30 September 2009 Padang earthquake (M 7.6) was a deep $(\sim 80 \mathrm{~km})$ intraplate earthquake that caused significant building damage in Padang with more than 1,000 casualties.

On 25 October 2010, a large earthquake (M 7.7) occurred off the west coast of the Mentawai Islands. According to the USGS, the origin time was 14:42:22 UTC (or 21:42:22 local time, or WIB), the epicenter was $3.484^{\circ} \mathrm{S}, 100.114^{\circ} \mathrm{E}$, and the depth was $20.6 \mathrm{~km}$. Badan Meteorologi Klimatologi Dan Geofisika (BMKG) of Indonesia estimated the magnitude as 7.2 and issued a tsunami warning within 5 min of the earthquake (Badan Meteorologi Klimatologi Dan 


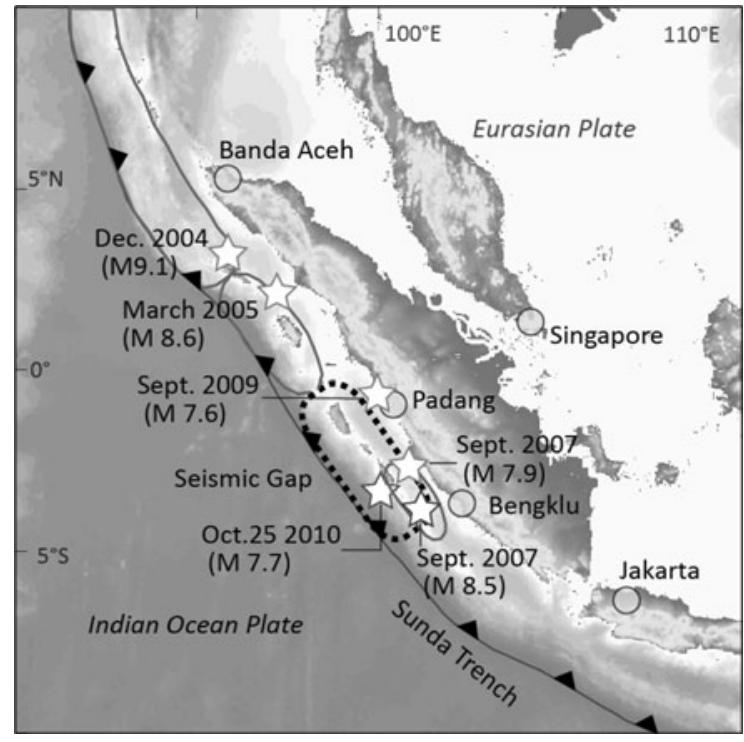

Figure 1

Tectonics and previous earthquakes off the west Sumatra Island

GeOFISIKA 2010). Without receiving information of tsunami damage, they cleared the tsunami warning $52 \mathrm{~min}$ after the earthquake.

Seismological analyses indicate that the Mentawai earthquake was a "tsunami earthquake," which produces much a larger tsunami than expected from the seismic magnitude. An Indonesian example is the 2006 Java $M_{w} 7.8$ earthquake, which triggered a tsunami with 21-m run-up (FuJII and SATAKE 2006; FRITZ et al., 2007). As with other tsunami earthquakes, the magnitude was larger at longer periods for the Mentawai earthquake. According to Newman et al. (2011) and the USGS, the short period body wave magnitude $\left(\mathrm{m}_{\mathrm{b}}\right.$ at $\left.\sim 1 \mathrm{~s}\right)$ was 6.5 , the highfrequency energy magnitude $\left(\mathrm{M}_{\mathrm{e}-\mathrm{hf}}\right.$ at $\left.0.5-2 \mathrm{~s}\right)$ was 6.9, the surface wave $(20 \mathrm{~s})$ magnitude $\left(\mathrm{M}_{\mathrm{s}}\right)$ was 7.3 , the energy magnitude $\left(\mathrm{M}_{\mathrm{e}}\right.$ up to $\left.100 \mathrm{~s}\right)$ was 7.3 , and the moment magnitude $\left(\mathrm{M}_{\mathrm{w}}\right)$ from the Centroid Moment Tensor inversion using longer waves ( $\sim 150 \mathrm{~s}$, Global CMT) or W phase (100-1,000 s) was 7.8. The tsunami magnitude $\left(\mathrm{M}_{\mathrm{t}}\right)$ computed from tsunami amplitudes at 15 tide gauges yielded 8.1. The duration of the earthquake was approximately 100-120 s (Newman et al., 2011; LAy et al., 2011; BILEK et al., 2011), which is unusually long compared to other earthquakes with similar magnitudes, such as

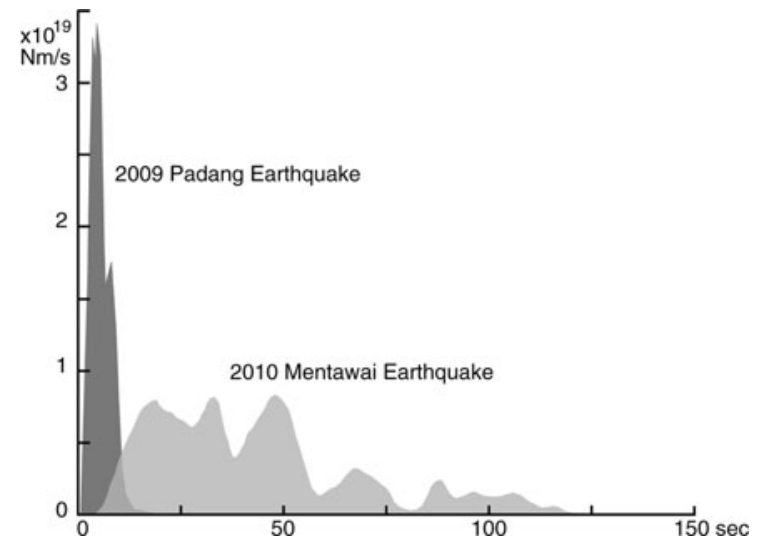

Figure 2

Source time functions, or seismic moment release rates, of the 2009 Padang (M 7.6) and 2010 Mentawai (M 7.7) earthquakes, estimated by finite fault modeling of the USGS

the 2009 Padang earthquake (Fig. 2). Large slip was located at a shallow part of the plate interface near the trench axis, with maximum slip ranging from $4.5 \mathrm{~m}$ (LAY et al., 2011), $4.7 \mathrm{~m}$ (BILEK et al., 2011) to $9.6 \mathrm{~m}$ (Newman et al., 2011). Newman et al. (2011) estimated the larger slip by considering the lower seismic velocity and rigidity. Modeling of near-field GPS and tsunami survey data also indicated shallow slip with a maximum of $9.7 \mathrm{~m}$ (HILL et al., 2012).

In this article, we first report our field survey results (Sect. 2). Sedimentary analysis of tsunami deposits was also carried out in our survey, but will be separately reported by PUTRA et al. (2012). Our Indonesian-Japanese team conducted the field survey 2 weeks after the earthquake when the sea conditions were very rough. This survey was followed by those of an Indonesian-German team (KERPEN et al., 2011) and an Indonesian-Singaporean-US team (HiLl et al., 2012). We also present instrumentally recorded tsunami waveforms (Sect. 3.1) and our modeling results of waveform inversion (Sects. 3.2 and 3.3). LAY et al. (2011) modeled the tsunami waveform recorded at a DART station, $\sim 1,600 \mathrm{~km}$ away from the epicenter, but other tsunami waveforms recorded at nearer stations have not been modeled. We further report detailed tsunami computation results from the tsunami source model (Sects. 3.4 and 3.5). 


\section{Tsunami Survey and Coastal Tsunami Heights}

\subsection{Method}

For the measurements of tsunami height, we used a total station to survey profiles of terrain and watermark elevations relative to sea level at the time of the survey. In most cases, we used traces on trees such as broken branches or debris to estimate the tsunami heights. Flow depth corresponds to the height of the trace above ground level (Fig. 3a). For tsunami heights, tidal corrections were made to calculate the heights above sea level at the time of tsunami arrival. We assumed that the tsunami arrival time was at 21:50 WIB on 25 October 2010 and used the predicted tide levels at Sikakap by using WXTide version 4.70 (Fig. 3b).
We measured the heights of 38 tsunami traces at eight locations (Table 1). The measured tsunami heights ranged from 2.5 to $9.3 \mathrm{~m}$, with an average and standard deviation of 5.4 and $3.9 \mathrm{~m}$, respectively. This indicated that the measured tsunami heights were mostly between 4 and $7 \mathrm{~m}$. Figure 4 shows the distribution of average tsunami heights at the eight locations. The largest tsunami heights were measured on the central and southern South Pagai and southwestern North Pagai Islands. The tsunami heights measured by KeRPEN et al. (2011) and Hill et al. (2012) were similar to ours on the Pagai Islands, whereas larger heights were measured on small islands west of South Pagai Island, with the extreme run-up height of $>16 \mathrm{~m}$ on Sibigau Island, west of Asahan (Hill et al., 2012).

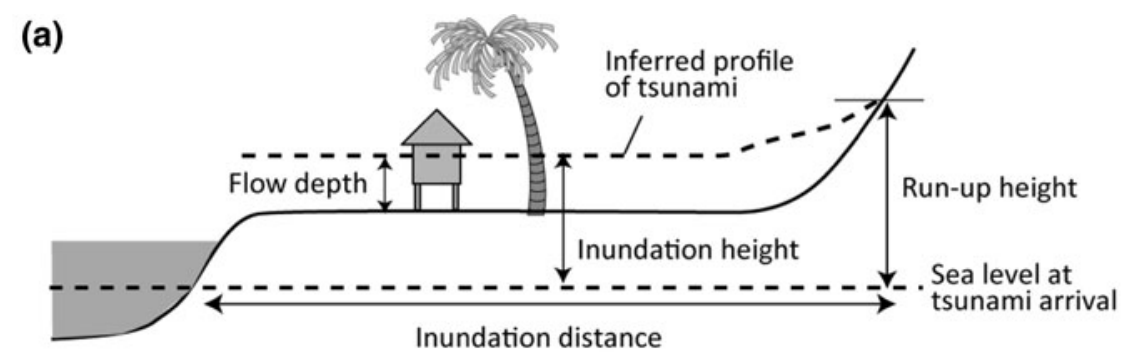

(b)

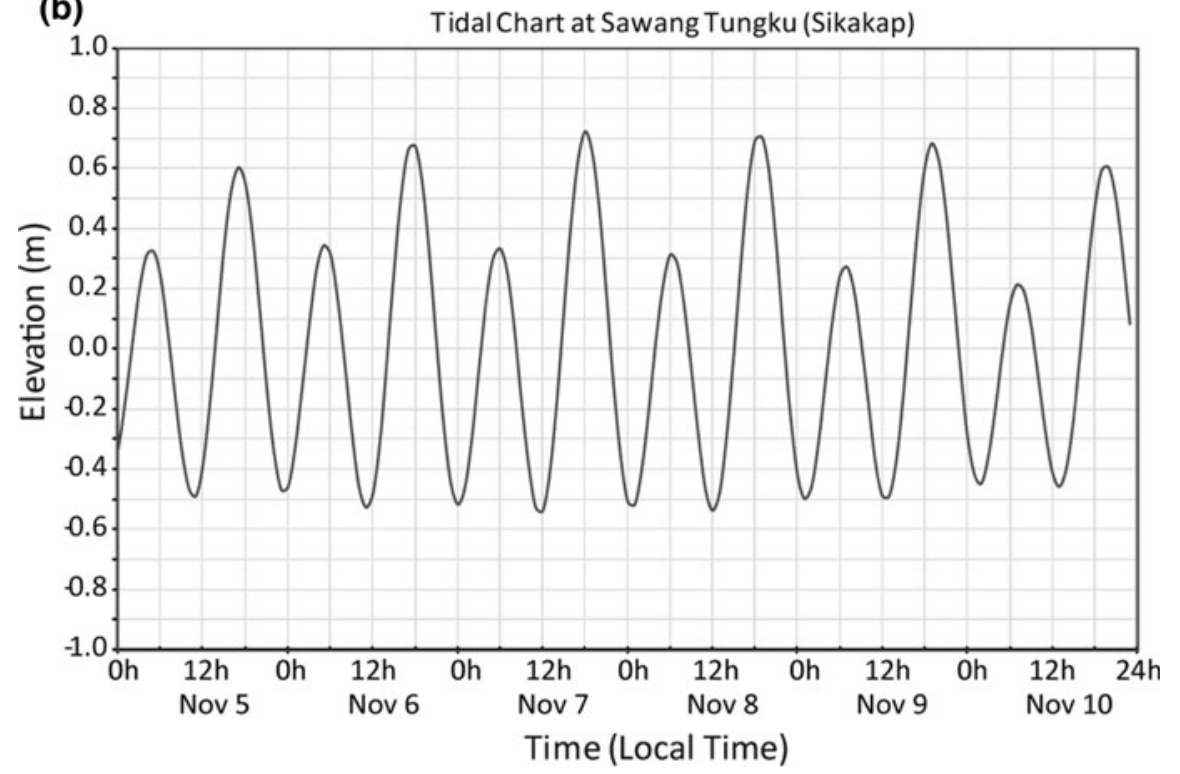

Figure 3

a Definitions of inundation distance, run-up height, tsunami (inundation) height, and flow depth. b Predicted tide level change at Sikakap during the survey period 
Table 1

Tsunami heights measured by the field survey

\begin{tabular}{|c|c|c|c|c|c|c|c|c|c|c|}
\hline & Site & Latitude & Longitude & $\begin{array}{l}\text { Tsunami } \\
\text { height } \\
\text { (m) }\end{array}$ & $\begin{array}{l}\text { Run-up } \\
\text { height } \\
(\mathrm{m})\end{array}$ & $\begin{array}{l}\text { Flow } \\
\text { depth } \\
\text { (m) }\end{array}$ & $\begin{array}{l}\text { Inundation } \\
\text { distance } \\
\text { (m) }\end{array}$ & Date & $\begin{array}{l}\text { Local } \\
\text { time } \\
\text { (hours) }\end{array}$ & Mark \\
\hline 1 & Asahan & $03^{\circ} 03^{\prime} 18^{\prime \prime} \mathrm{S}$ & $100^{\circ} 14^{\prime} 13^{\prime \prime} \mathrm{E}$ & 6.4 & & 6.0 & 41 & 06-Nov-2010 & 1424 & BB \\
\hline 2 & Asahan & $03^{\circ} 03^{\prime} 18^{\prime \prime} \mathrm{S}$ & $100^{\circ} 14^{\prime} 13^{\prime \prime} \mathrm{E}$ & 9.3 & & & 38 & 06-Nov-2010 & 1424 & BB \\
\hline 3 & Asahan & $03^{\circ} 03^{\prime} 18^{\prime \prime} \mathrm{S}$ & $100^{\circ} 14^{\prime} 13^{\prime \prime} \mathrm{E}$ & 6.6 & & 6.6 & 9 & 06-Nov-2010 & 1424 & BB \\
\hline 4 & Purorougat & $03^{\circ} 02^{\prime} 12^{\prime \prime} \mathrm{S}$ & $100^{\circ} 13^{\prime} 55^{\prime \prime} \mathrm{E}$ & & & 5.5 & & 06-Nov-2010 & & $\mathrm{BB}$ \\
\hline 5 & Lopon Lakau & $03^{\circ} 12^{\prime} 39^{\prime \prime} \mathrm{S}$ & $100^{\circ} 21^{\prime} 02^{\prime \prime} \mathrm{E}$ & 2.5 & & & 23 & 07-Nov-2010 & 0840 & $\mathrm{BB}$ \\
\hline 6 & Maonai & $03^{\circ} 11^{\prime} 31^{\prime \prime} \mathrm{S}$ & $100^{\circ} 20^{\prime} 41^{\prime \prime} \mathrm{E}$ & 6.8 & & 3.9 & 259 & 07-Nov-2010 & 1130 & $\mathrm{BB}$ \\
\hline 7 & Maonai & $03^{\circ} 11^{\prime} 33^{\prime \prime} \mathrm{S}$ & $100^{\circ} 20^{\prime} 38^{\prime \prime} \mathrm{E}$ & 6.9 & & 3.8 & 182 & 07-Nov-2010 & 1130 & $\mathrm{RD}$ \\
\hline 8 & Maonai & $03^{\circ} 11^{\prime} 34^{\prime \prime} \mathrm{S}$ & $100^{\circ} 20^{\prime} 39^{\prime \prime} \mathrm{E}$ & 6.7 & & 3.6 & 181 & 07-Nov-2010 & 1130 & $\mathrm{BB}$ \\
\hline 9 & Maonai & $03^{\circ} 11^{\prime} 36^{\prime \prime} \mathrm{S}$ & $100^{\circ} 20^{\prime} 39^{\prime \prime} \mathrm{E}$ & 6.7 & & 3.5 & 206 & 07-Nov-2010 & 1130 & $\mathrm{BB}$ \\
\hline 10 & Maonai & $03^{\circ} 11^{\prime} 30^{\prime \prime} \mathrm{S}$ & $100^{\circ} 20^{\prime} 42^{\prime \prime} \mathrm{E}$ & & 7.3 & 0.0 & 315 & 07-Nov-2010 & 1130 & ER, EW \\
\hline 11 & Sabeu Gunggung & $02^{\circ} 48^{\prime} 59^{\prime \prime} \mathrm{S}$ & $100^{\circ} 03^{\prime} 29^{\prime \prime} \mathrm{E}$ & 5.0 & & 3.9 & 31 & 08-Nov-2010 & 0900 & $\mathrm{BB}$ \\
\hline 12 & Sabeu Gunggung & $02^{\circ} 48^{\prime} 57^{\prime \prime} \mathrm{S}$ & $100^{\circ} 03^{\prime} 28^{\prime \prime} \mathrm{E}$ & 5.8 & & 3.9 & 75 & 08-Nov-2010 & 0900 & $\mathrm{BB}$ \\
\hline 13 & Sabeu Gunggung & $02^{\circ} 48^{\prime} 57^{\prime \prime} \mathrm{S}$ & $100^{\circ} 03^{\prime} 28^{\prime \prime} \mathrm{E}$ & 7.0 & & 4.8 & 75 & 08-Nov-2010 & 0900 & BB \\
\hline 14 & Sabeu Gunggung & $02^{\circ} 48^{\prime} 52^{\prime \prime} \mathrm{S}$ & $100^{\circ} 03^{\prime} 28^{\prime \prime} \mathrm{E}$ & 4.3 & & 4.3 & 217 & 08-Nov-2010 & 0900 & $\mathrm{BB}$ \\
\hline 15 & Muntei & $02^{\circ} 49^{\prime} 46^{\prime \prime} \mathrm{S}$ & $100^{\circ} 05^{\prime} 46^{\prime \prime} \mathrm{E}$ & 5.7 & & 3.8 & 287 & 08-Nov-2010 & 1411 & $\mathrm{BB}$ \\
\hline 16 & Muntei & $02^{\circ} 49^{\prime} 46^{\prime \prime} \mathrm{S}$ & $100^{\circ} 05^{\prime} 46^{\prime \prime} \mathrm{E}$ & 4.6 & & 1.6 & 241 & 08-Nov-2010 & 1411 & BB \\
\hline 17 & Muntei & $02^{\circ} 49^{\prime} 53^{\prime \prime} \mathrm{S}$ & $100^{\circ} 05^{\prime} 41^{\prime \prime} \mathrm{E}$ & 4.6 & & 3.4 & 3 & 08-Nov-2010 & 1411 & $\mathrm{BB}$ \\
\hline 18 & Muntei & $02^{\circ} 49^{\prime} 46^{\prime \prime} \mathrm{S}$ & $100^{\circ} 05^{\prime} 46^{\prime \prime} \mathrm{E}$ & 7.8 & & 5.7 & 265 & 08-Nov-2010 & 1411 & $\mathrm{BB}$ \\
\hline 19 & Muntei & $02^{\circ} 49^{\prime} 53^{\prime \prime} \mathrm{S}$ & $100^{\circ} 05^{\prime} 44^{\prime \prime} \mathrm{E}$ & 4.6 & & 3.0 & 76 & 08-Nov-2010 & 1411 & $\mathrm{BB}$ \\
\hline 20 & Muntei & $02^{\circ} 49^{\prime} 53^{\prime \prime} \mathrm{S}$ & $100^{\circ} 05^{\prime} 44^{\prime \prime} \mathrm{E}$ & 4.6 & & 3.0 & 89 & 08-Nov-2010 & 1411 & $\mathrm{RD}$ \\
\hline 21 & Muntei & $02^{\circ} 49^{\prime} 53^{\prime \prime} \mathrm{S}$ & $100^{\circ} 05^{\prime} 47^{\prime \prime} \mathrm{E}$ & 5.1 & & 3.6 & 133 & 08-Nov-2010 & 1411 & $\mathrm{BB}$ \\
\hline 22 & Muntei & $02^{\circ} 49^{\prime} 42^{\prime \prime} \mathrm{S}$ & $100^{\circ} 05^{\prime} 48^{\prime \prime} \mathrm{E}$ & & 4.8 & 0.0 & 423 & 08-Nov-2010 & 1411 & $\mathrm{SD}$ \\
\hline 23 & Muntei & $02^{\circ} 49^{\prime} 50^{\prime \prime} \mathrm{S}$ & $100^{\circ} 05^{\prime} 32^{\prime \prime} \mathrm{E}$ & 8.8 & & & & 08-Nov-2010 & 1628 & $\mathrm{BB}$ \\
\hline 24 & Muntei & $02^{\circ} 49^{\prime} 56^{\prime \prime} \mathrm{S}$ & $100^{\circ} 05^{\prime} 30^{\prime \prime} \mathrm{E}$ & 6.8 & & & & 08-Nov-2010 & 1628 & $\mathrm{RD}$ \\
\hline 25 & Muntei & $02^{\circ} 49^{\prime} 57^{\prime \prime} \mathrm{S}$ & $100^{\circ} 05^{\prime} 29^{\prime \prime} \mathrm{E}$ & 4.5 & & & & 08-Nov-2010 & 1628 & $\mathrm{BB}$ \\
\hline 26 & Macaroni & $02^{\circ} 46^{\prime} 37^{\prime \prime} \mathrm{S}$ & $99^{\circ} 58^{\prime} 59^{\prime \prime} \mathrm{E}$ & 4.6 & & 3.0 & 20 & 09-Nov-2010 & 0905 & BB \\
\hline 27 & Macaroni & $00^{\circ} 46^{\prime} 37^{\prime \prime} \mathrm{S}$ & $99^{\circ} 58^{\prime} 59^{\prime \prime} \mathrm{E}$ & 4.9 & & 3.8 & 19 & 09-Nov-2010 & 0905 & $\mathrm{BB}$ \\
\hline 28 & Macaroni & $02^{\circ} 46^{\prime} 40^{\prime \prime} \mathrm{S}$ & $99^{\circ} 58^{\prime} 57^{\prime \prime} \mathrm{E}$ & 2.9 & & 1.2 & 70 & 09-Nov-2010 & 0905 & MO \\
\hline 29 & Macaroni & $02^{\circ} 46^{\prime} 40^{\prime \prime} \mathrm{S}$ & $99^{\circ} 58^{\prime} 57^{\prime \prime} \mathrm{E}$ & 2.9 & & 1.2 & 77 & 09-Nov-2010 & 0905 & MO \\
\hline 30 & Macaroni & $02^{\circ} 46^{\prime} 41^{\prime \prime} \mathrm{S}$ & $99^{\circ} 58^{\prime} 58^{\prime \prime} \mathrm{E}$ & 3.0 & & 1.2 & 115 & 09-Nov-2010 & 0905 & MO \\
\hline 31 & Macaroni & $02^{\circ} 46^{\prime} 41^{\prime \prime} \mathrm{S}$ & $99^{\circ} 59^{\prime} 01^{\prime \prime} \mathrm{E}$ & 3.8 & & 2.7 & 177 & 09-Nov-2010 & 0905 & $\mathrm{BB}$ \\
\hline 32 & Macaroni & $02^{\circ} 46^{\prime} 40^{\prime \prime} \mathrm{S}$ & $99^{\circ} 59^{\prime} 00^{\prime \prime} \mathrm{E}$ & 4.8 & & 3.3 & 160 & 09-Nov-2010 & 0905 & $\mathrm{BB}$ \\
\hline 33 & Macaroni & $02^{\circ} 46^{\prime} 40^{\prime \prime} \mathrm{S}$ & $99^{\circ} 59^{\prime} 00^{\prime \prime} \mathrm{E}$ & 5.4 & & 4.0 & 166 & 09-Nov-2010 & 0905 & $\mathrm{BB}$ \\
\hline 34 & Tumalei & $02^{\circ} 37^{\prime} 27^{\prime \prime} \mathrm{S}$ & $99^{\circ} 58^{\prime} 48^{\prime \prime} \mathrm{E}$ & 4.0 & & & 6 & 09-Nov-2010 & 1339 & $\mathrm{BB}$ \\
\hline 35 & Tumalei & $02^{\circ} 37^{\prime} 27^{\prime \prime} \mathrm{S}$ & $99^{\circ} 58^{\prime} 48^{\prime \prime} \mathrm{E}$ & 5.2 & & & 9 & 09-Nov-2010 & 1339 & $\mathrm{BB}$ \\
\hline 36 & Tumalei & $02^{\circ} 37^{\prime} 30^{\prime \prime} \mathrm{S}$ & $99^{\circ} 58^{\prime} 50^{\prime \prime} \mathrm{E}$ & & 4.6 & 0.0 & 136 & 09-Nov-2010 & 1339 & $\mathrm{SD}, \mathrm{ER}$ \\
\hline 37 & Tumalei & $02^{\circ} 37^{\prime} 25^{\prime \prime} \mathrm{S}$ & $99^{\circ} 58^{\prime} 45^{\prime \prime} \mathrm{E}$ & 4.7 & & & 46 & 09-Nov-2010 & 1425 & $\mathrm{BB}$ \\
\hline 38 & Tumalei & $02^{\circ} 37^{\prime} 25^{\prime \prime} \mathrm{S}$ & $99^{\circ} 58^{\prime} 45^{\prime \prime} \mathrm{E}$ & 5.5 & & & 36 & 09-Nov-2010 & 1425 & BB \\
\hline 39 & Tumalei & $02^{\circ} 37^{\prime} 26^{\prime \prime} \mathrm{S}$ & $99^{\circ} 58^{\prime} 46^{\prime \prime} \mathrm{E}$ & 6.1 & & & 20 & 09-Nov-2010 & 1444 & $\mathrm{BB}$ \\
\hline
\end{tabular}

$B B$ broken branch, $E R$ erosion, $M O$ mudline outside, $R D$ rafted debris, $S D$ sediment deposit

\section{Tsunami Height Distributions}

\subsection{Asahan and Purorougat}

On the Asahan coast, facing the mouth of a $\sim 2$ km-wide bay on the west coast of South Pagai Island, a large coral boulder ( $\sim 1 \mathrm{~m}$ diameter $)$ was transported $\sim 70 \mathrm{~m}$ beyond a beach ridge of $\sim 3 \mathrm{~m}$ altitude. Traces on trees indicated tsunami heights of 6.4-9.3 m, with an average of $7.4 \mathrm{~m}$ (Fig. 6a). These were the largest tsunami heights measured by our survey. On the contrary, in Asahan village, located near the head of the bay, no tsunami damage occurred. At Purorougat, facing a smaller $(\sim 0.5 \mathrm{~km}$ wide), U-shaped bay, the tsunami washed away most houses, and 75 out of 235 residents lost their lives. A trace on a tree indicated a flow depth of $\sim 5.5 \mathrm{~m}$. 


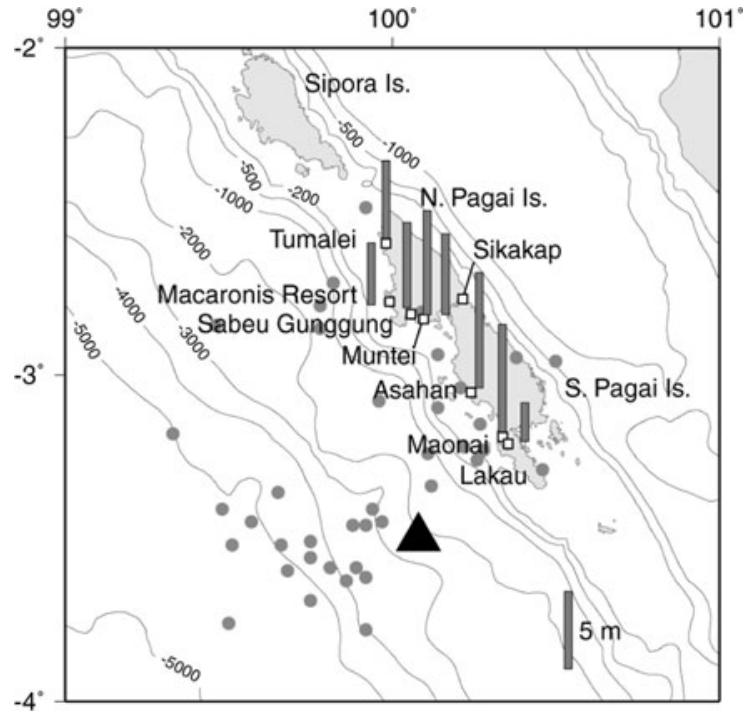

Figure 4

Map showing the location of survey sites (white squares). The average tsunami height at each location is shown by gray bars. For Muntei, two bars (in the village and the outer coasts) are shown. Locations (according to USGS) of the mainshock (black triangle) and aftershocks (gray circles), which occurred within 1 day of the mainshock, are also shown

\subsection{Lopon Lakau}

Located in a bay $\sim 2 \mathrm{~km}$ wide on the southwest coast of South Pagai Island, Lopon Lakau (a logging port) was damaged by the tsunami. Numerous coral boulders were found on the beach, and a trace on a tree indicated a $2.5-\mathrm{m}$ tsunami height. At Lakau village, an eyewitness recounted that the ground shaking was strong enough for him to be awakened. Having heard an airplane-like loud noise, villagers escaped inland, and all survived.

\subsection{Maonai}

Located at the end of a $U$-shaped bay $(\sim 0.5 \mathrm{~km}$ wide) on the southwest coast of South Pagai Island, this village also suffered significantly from the tsunami. On both sides of the bay, the tsunami deposited numerous large $(\sim 2 \mathrm{~m}$ diameter $)$ coral boulders. The inundation distance was $>470 \mathrm{~m}$. Five measurements of traces on trees indicated that the tsunami heights were $6.7-7.3 \mathrm{~m}$, with an average of $6.9 \mathrm{~m}$ (Fig. 5a). The flow depth ranged from 3.5 to $3.9 \mathrm{~m}$. The entire village was washed away (Fig. 6b), and the casualties were 38 out of the original population of 139 .

\subsection{Sabeu Gunggung}

Located on the end of a U-shaped bay $(\sim 3 \mathrm{~km}$ wide) on the southwestern coast of North Pagai Island, this village suffered significantly from the tsunami. We surveyed a profile up to $\sim 300 \mathrm{~m}$ from the coast, but could not reach the inundation limit because of the river in the back of the village. The tsunami height was 4.3-7.0 m (average of four measurements was $5.5 \mathrm{~m}$ ) measured on a surface $\sim 2 \mathrm{~m}$ above the sea level (Fig. 5b). The flow depth ranged from 3.9 to $4.8 \mathrm{~m}$. There had been 65 houses, but none remained. Of the original population of 260, 120 people lost their lives (Fig. 6c). According to a survivor, ground shaking was not strong, and he escaped after hearing a loud sound $\sim 5 \mathrm{~min}$ after the shaking. Some people were watching TV and saw running text of a tsunami warning, but the tsunami was arriving at that time.

\subsection{Muntei Barubaru}

Located $\sim 5 \mathrm{~km}$ SE of Sabeu Gunggung, this village faces into a small $\mathrm{V}$-shaped bay approximately $1 \mathrm{~km}$ wide. The inundation distance was $\sim 420 \mathrm{~m}$, with a run-up height of $4.8 \mathrm{~m}$ : the tsunami heights ranged from 4.6 to $5.7 \mathrm{~m}$ with one exceptional measurement of $7.8 \mathrm{~m}$ (Fig. $5 \mathrm{c}$ ). The average of the eight measurements was $5.2 \mathrm{~m}$. Many large $(\sim 2 \mathrm{~m}$ diameter) coral boulders were also transported onto land, and the entire village was washed away (Fig. 6d). Of the original population of 310, 149 lost their lives. On the opposite (western) side of the bay, traces on trees indicate tsunami heights ranging from 3.9 to $8.8 \mathrm{~m}$, with an average of $6.0 \mathrm{~m}$ of the four measurements.

\subsection{Macaronis Resort}

Located on a $\sim 2$-km-long peninsula, extending in the SW direction, at the western tip of North Pagai Island, this resort consisted of a main hotel tower (Fig. 6e), several single-story buildings, and beach cottages. The main tower was damaged on the ground floor; however, it remained standing while the second and higher floors provided shelter for approximately 20 

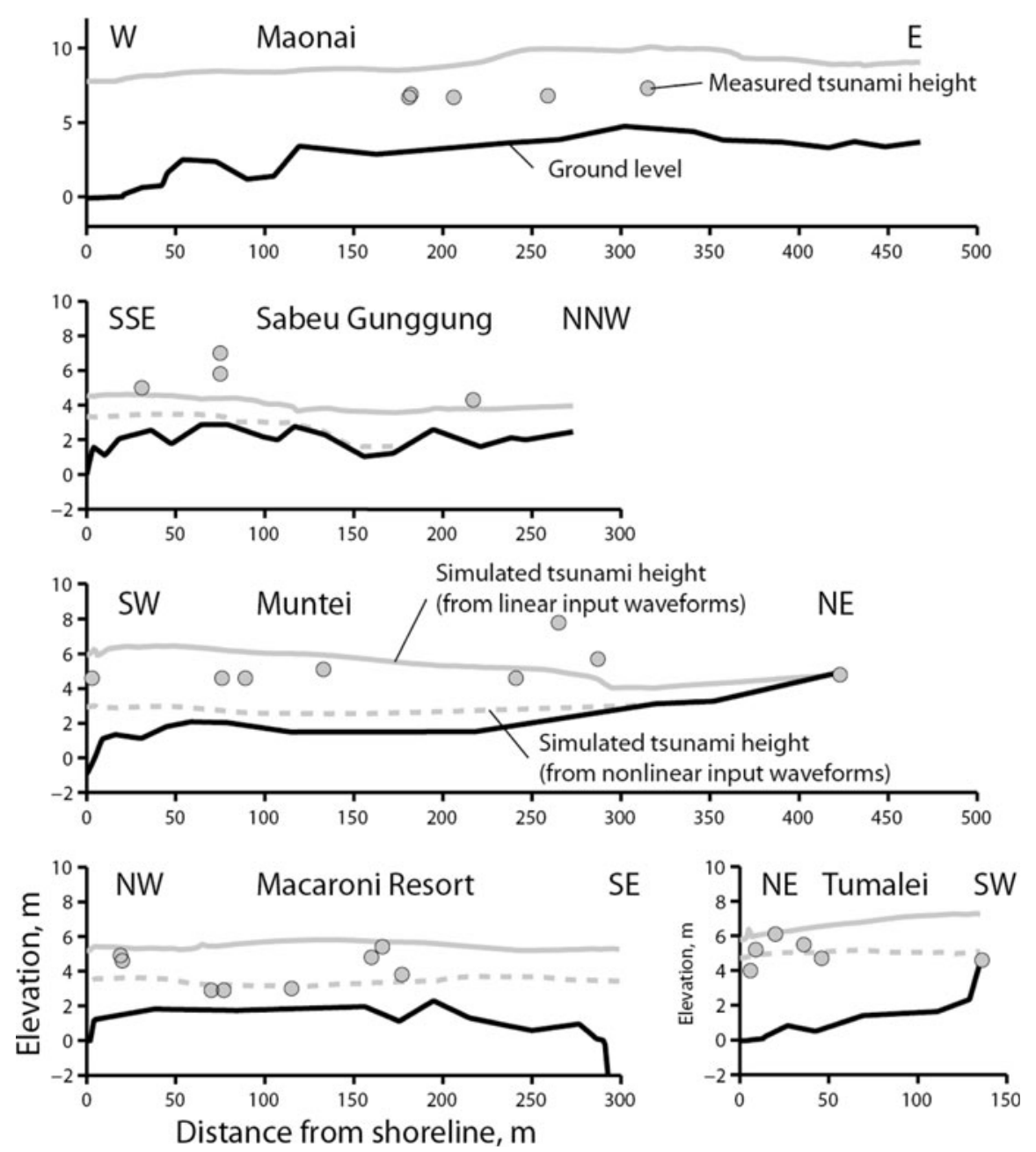

Figure 5

Topographic profile (thick solid lines) and tsunami heights (gray circles) at five locations. Solid gray lines represent simulated water levels using one-dimensional computation from input waveforms of linear computation, while dashed gray lines represent simulated water levels from input waveforms of nonlinear computation (see Sect. 3.5)

guests, all of whom survived. The cottages on the beach were all washed away, and the buildings were also damaged. We surveyed across the peninsula (Fig. 5d) and found that the tsunami arrived from both directions. Clear watermarks on the building indicated that the flow depth was $\sim 1.2 \mathrm{~m}$ on the peninsula $(\sim 2 \mathrm{~m}$ above sea level). Higher tsunami traces ranging from 2.9 to $5.4 \mathrm{~m}$ were found on trees, with an average tsunami height of $4.0 \mathrm{~m}$ based on eight measurements.

\subsection{Tumalei}

Located on the northwest coast of North Pagai Island, in a small bay facing north, the main village, with a population of approximately 200 , was on a flat area $\sim 100 \mathrm{~m}$ wide flanked by a steep hill. The tsunami height ranged from 4.0 to $6.1 \mathrm{~m}$, and the average of six measurements was $5.0 \mathrm{~m}$. The inundation distance was $\sim 140 \mathrm{~m}$ to the hill slope (Fig. 5e). Most houses were washed to the base of the hill, but some were not completely broken (Fig. 6f). Given the proximity to the hill, the residents spontaneously escaped to high ground. In addition, tsunami education and training had been conducted by national and foreign Non-Governmental Organizations (NGOs), such as TimPB and SurfAID, with four drills since 2008. These factors contributed to the small number of fatalities. 

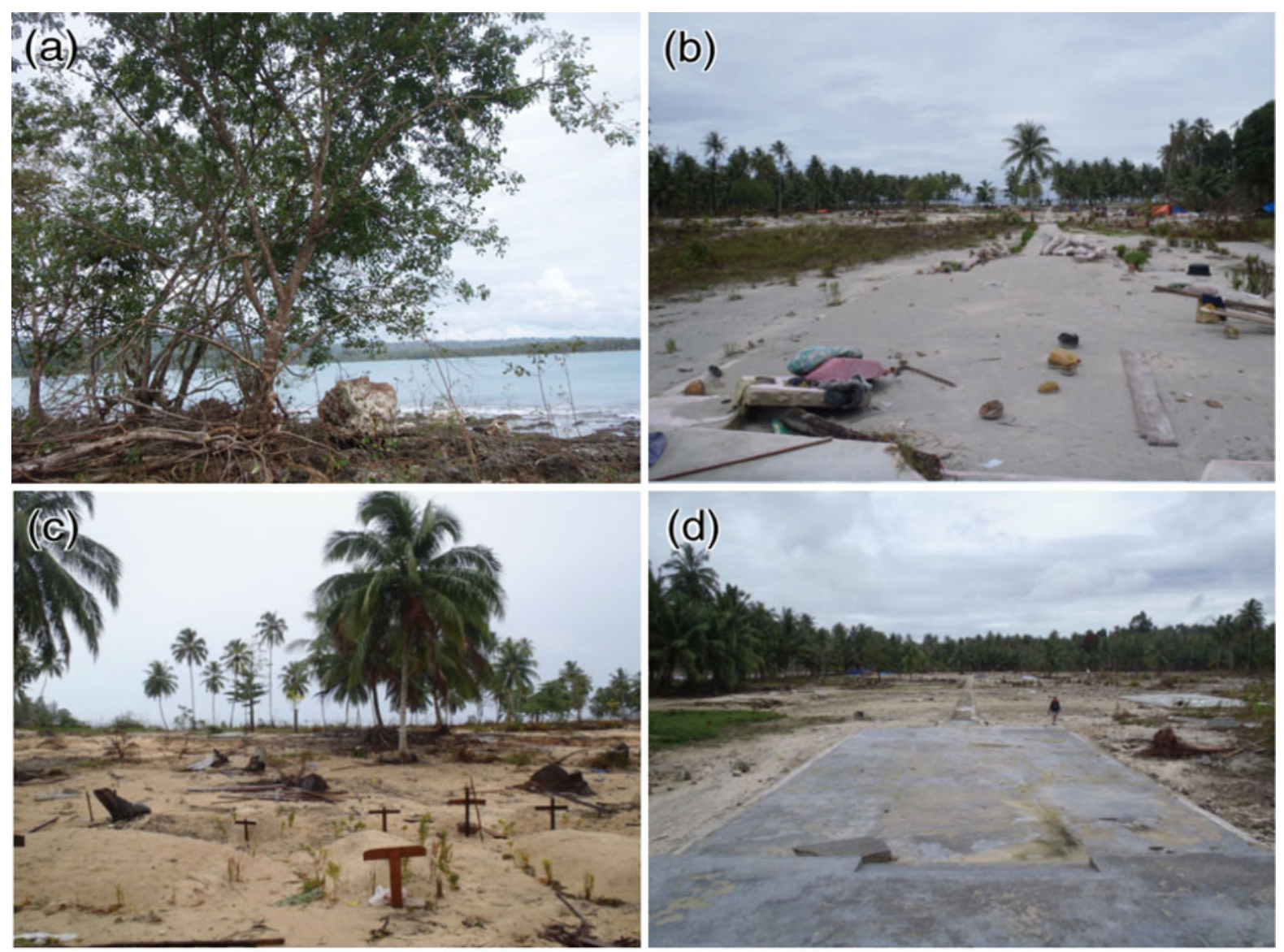

(e)

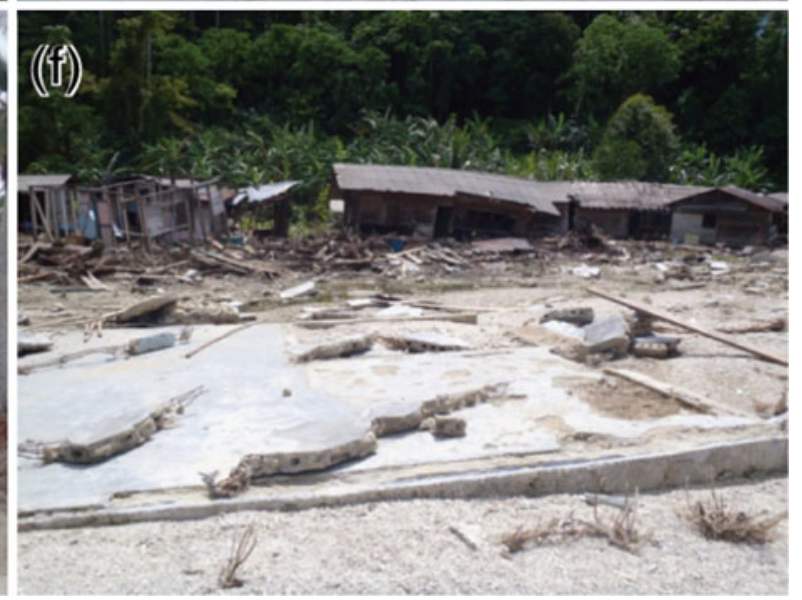

Figure 6

Photographs of the effects of the tsunami at: a Asahan, b Maonai, c Sabeu Gunggung, d Muntei, e Macaroni Resort, and f Tumalei

\section{Tsunami Modeling}

\subsection{Observed Tsunami Waveforms}

The tsunami was recorded at more than ten tide gauge stations around the Indian Ocean, including four tide gauge stations in Indonesia (Padang, Enggano, Tanahbala, and Telukdalam; Fig. 7). In addition, the tsunami was recorded on a surface GPS buoy (GITEWS SUMATRA-03) located off Mentawai just west of the source area and a DART station 


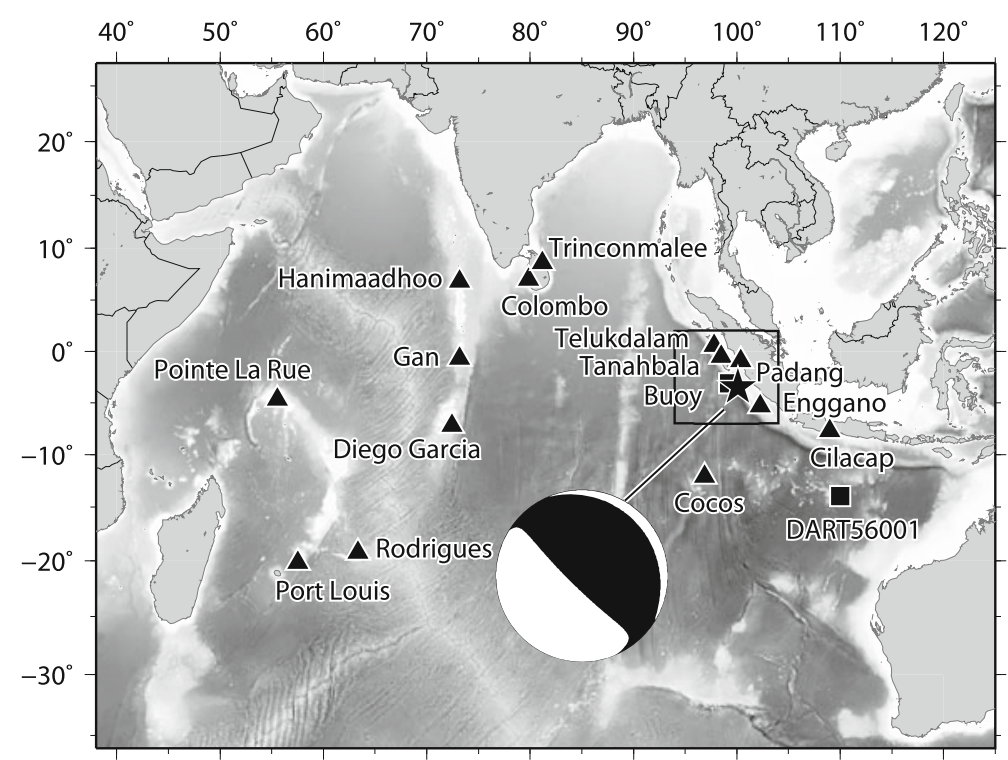

Figure 7

Locations of tide gauge, GPS buoy, and DART stations used for the inversion. Rectangle shows the computation area with a $12^{\prime \prime}$ grid interval for a near-field tsunami propagation. The focal mechanism of the USGS W-phase moment tensor solution is also shown

56001, $\sim 1,600 \mathrm{~km}$ southeast of the epicenter. The tsunami waveforms were collected from the websites of the West Coast/Alaska Tsunami Warning Center (WCATWC http://wcatwc.arh.noaa.gov/), Flanders Marine Institute (VLIZ http://www.ioc-sealevelmoni toring.org/) of UNESCO/IOC, and the National Oceanic and Atmospheric Administration (NOAA, http://nctr.pmel.noaa.gov/Dart/), and are shown in Fig. 8.

Within 10 min of the earthquake, the Mentawai buoy recorded two pulses of tsunami waves with amplitudes of $\sim 15 \mathrm{~cm}$ and a period of a few minutes. At Padang, the nearest tide gauge station, the tsunami started with a small negative pulse at approximately $1 \mathrm{~h}$ after the earthquake, followed by a crest of $\sim 0.3 \mathrm{~m}$. The tsunami amplitudes were mostly $<0.1 \mathrm{~m}$ at other stations in Indonesia, Sri Lanka, and Maldives. Notable exceptions were at Rodrigues and Port Louis (Mauritius) where a second wave with $\sim 0.2 \mathrm{~m}$ amplitude arrived $\sim 6$ and $\sim 7 \mathrm{~h}$ after the earthquake, respectively. The tsunami was also recorded at $\mathrm{La}$ Reunion Island with amplitude $\sim 0.2 \mathrm{~m}$ (SAHAL and Morin 2012). At the DART station, the tsunami arrived at $\sim 2 \mathrm{~h}$ after the earthquake with an amplitude of just $0.01 \mathrm{~m}$.

\subsection{Tsunami Computation and Bathymetry Data}

We carried out three types of tsunami numerical computations. The first one was in the entire Indian Ocean for the inversion of the observed tsunami waveforms to estimate the earthquake slip distribution (Sect. 3.3). The second one was a more detailed computation around the Pagai Islands with tsunami inundation to compare with the measured tsunami heights (Sect. 3.4). The third type involved a onedimensional computation based on the measured topographic profiles at selected sites (Sect. 3.5).

For the tsunami propagation in the Indian Ocean, we computed tsunami waveforms by using linear computations on a spherical coordinate system (SATAKe 1995). The computational region is as shown in Fig. 7 with grid interval of $2^{\prime}(\sim 3.7 \mathrm{~km})$. Near the tide gauge stations, finer $\left(24^{\prime \prime}, \sim 0.74 \mathrm{~km}\right)$ grids were adopted. The bathymetric data was resampled from GEBCO_08 30" gridded data. Around the Indonesian tide gauge stations (Padang, Enggano, Tanahbalah, and Telukdalam), we made $12^{\prime \prime}(\sim 0.37 \mathrm{~km})$ grid data from GEBCO_08 and Indonesian Navy charts.

For the computations around the Pagai Islands, we used a system of nested grids. The largest domain that included the source region had a $27^{\prime \prime}(\sim 833 \mathrm{~m})$ grid, 

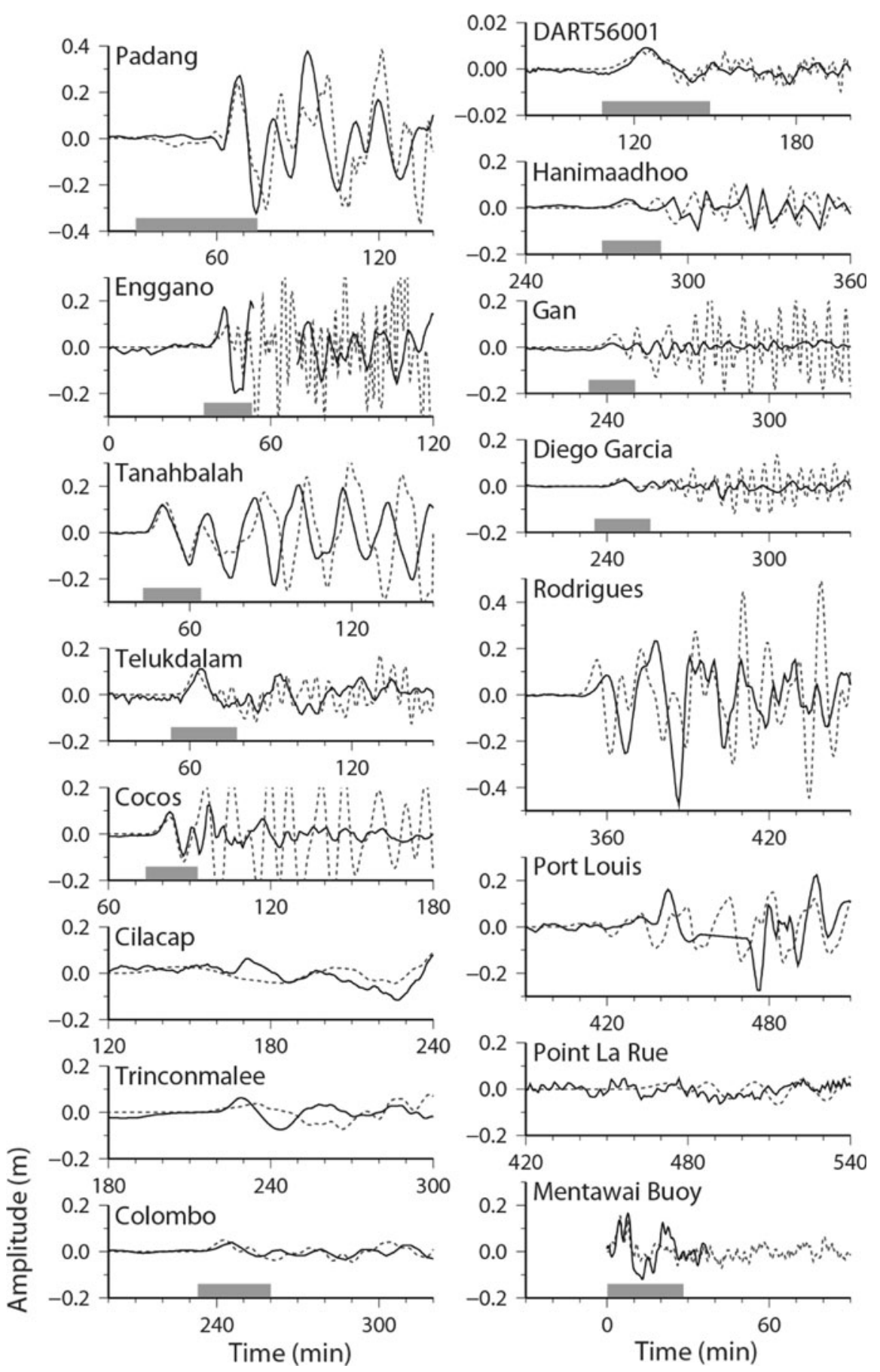

Figure 8

Tsunami waveforms recorded at the coastal tide gauge, GPS buoy, and DART stations (black solid curves), and computed from our final model (gray dashed curves). The locations of the gauges are shown in Fig. 7. Thick gray bars above the time axis indicate the time range used in the inversions to match the observed and synthetic waveforms. The waveforms at stations without bars (Cilacap, Trinconmalee, Rodrigues, Port Luis and Point La Rue) are not used for inversion 

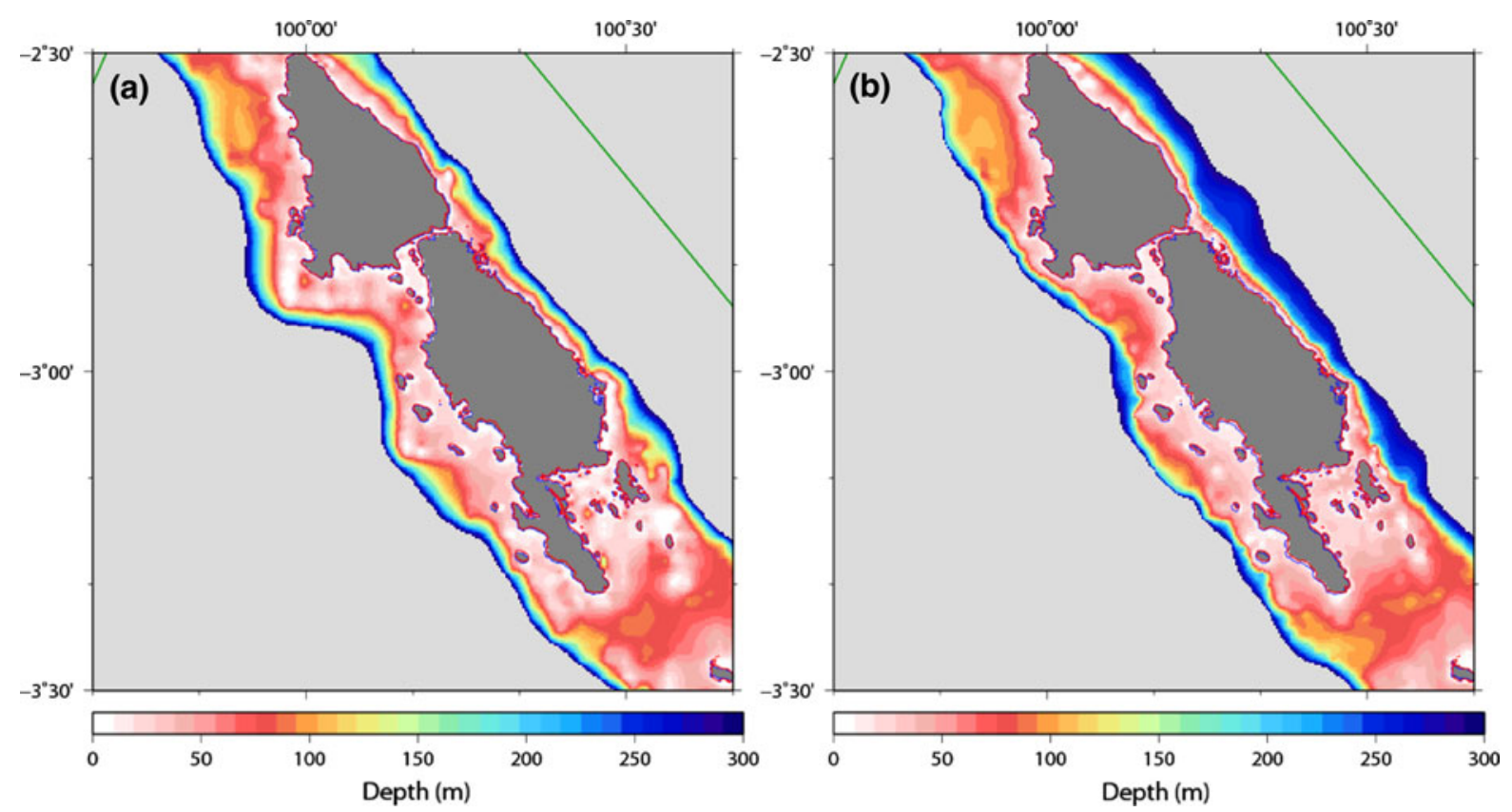

Figure 9

Nearshore bathymetry data around the Pagai Islands. a GEBCO_08 data. b Digitized Navy charts (241, 242, and 277)

while the finest domain had a $1^{\prime \prime}(\sim 30 \mathrm{~m})$ grid. For the coarser domains $\left(27^{\prime \prime}\right.$ and $\left.9^{\prime \prime}\right)$, the linear shallowwater equations were used, while at the finer domains $\left(3^{\prime \prime}\right.$ and $\left.1^{\prime \prime}\right)$, both linear computation and nonlinear computation with inundation were made. For these detailed computations, we merged ETOPO1 data with Indonesian Navy chart data at the 200-m contour depth, and modified the coastline and SRTM data, as described below.

For the one-dimensional tsunami inundation simulations along the surveyed transect lines, the nonlinear shallow-water equations were solved using a finite difference scheme in the Cartesian coordinate system (Gusman et al., 2012). For this computation, tsunami waveforms computed in the detailed simulation at points several hundreds meters from the shoreline at a water depth of $\sim 5 \mathrm{~m}$ were used as input waveforms. Tsunami inundation along a surveyed topographic profile was computed with a 1-m grid size.

We found that publicly available bathymetric data, such as GEBCO_08 or ETOPO1, as well as SRTM topographic data, were not very accurate around the Pagai Islands. Comparison of GEBCO_08 and Indonesian Navy chart data around the Pagai
Islands (Fig. 9) indicated that the GEBCO_08 data showed abnormally shallow areas off the west coast of the Pagai Islands. In addition, the coastlines are different between the GEBCO_08 and Navy Chart data. Various satellite imagery maps were made and provided by the Center for Satellite Based Crisis Information (ZKI) of the German Aerospace Center (DLR) and the Centre for Remote Imaging, Sensing, and Processing (CRISP) of the National University of Singapore (NUS). Comparisons of these images indicated that the coastlines in the Navy charts were more accurate. We therefore manually digitized the coastlines and water depth points from the Indonesian Navy Charts (241, 242, and 277) and made nearshore bathymetry extending to the $200 \mathrm{~m}$ depth contour. We then merged this data with the GEBCO or ETOPO1 data. For the finer domains ( $3^{\prime \prime}$ and $\left.1^{\prime \prime}\right)$, we directly digitized the coastlines from the satellite images.

For the topography data of the Pagai Islands, we compared the Shuttle Radar Topography Mission (SRTM) data (1" grid) provided by the US National Aeronautics and Space Administration (NASA) with topographic profile data obtained through a field survey, and found that the SRTM data were 
consistently higher by several meters, likely because of the vegetation effects. Therefore, we reduced $7 \mathrm{~m}$ in elevation from the SRTM data to form the topography data and then merged this with the bathymetry data.

\subsection{Tsunami Inversion and Slip Distribution}

We estimated the slip distribution on the fault plane through the inversion of tsunami waveforms. We divided the tsunami source area into 28 subfaults and located them on the source area. The strike and rake were estimated from USGS W phase solution (Fig. 7), while the dip angles were assumed to be $7.5^{\circ}$ and $12^{\circ}$ for shallower and deeper subfaults, following the seismic reflection images of SINGH et al., (2011). The fault parameters are given in Table 2. We computed the seafloor deformation for a unit slip on each subfault by using the formula of OKADA (1985). The effect of horizontal movements for the seafloor slope (TANIOKA and SATAKe 1996) was also considered. We used the computed seafloor deformation as an initial condition to compute the tsunami waveforms at tide gauge, GPS buoy, and DART locations. We used them as Green's functions for the inversion. The details of tsunami computations and inversion are described in (FuJI and SATAKE 2007). We weighted the DART data ten times, because the amplitudes were smaller (note that the vertical scale in Fig. 8 is 10 times smaller). In addition, we weighted the nearby buoy data and initial part of the Padang waveforms as twice as large as the other stations to obtain a better match between the observed and computed wavefroms (Fig. 8). We did not use the waveforms at Rodrigues and Port Louis, because the computed and observed travel times do not match well, probably because of the large distance and dispersion effects.

The result of the waveform inversion is shown in Fig. 10a and Table 2. This shows that most slip

Table 2

Fault parameters and slip amounts of subfaults for the inversion

\begin{tabular}{|c|c|c|c|c|c|c|c|c|c|}
\hline No. & Length (km) & Width (km) & Depth $(\mathrm{km})$ & Strike (deg) & Dip (deg) & Rake (deg) & Slip (m) & Lat (deg) & Long (deg) \\
\hline 1 & 30 & 30 & 2 & 326 & 7.5 & 101 & 1.83 & -4.34144 & 100.10976 \\
\hline 2 & 30 & 30 & 2 & 326 & 7.5 & 101 & 0.00 & -4.11777 & 99.95845 \\
\hline 3 & 30 & 30 & 2 & 326 & 7.5 & 101 & 1.16 & -3.89410 & 99.80719 \\
\hline 4 & 30 & 30 & 2 & 326 & 7.5 & 101 & 6.10 & -3.67043 & 99.65597 \\
\hline 5 & 30 & 30 & 2 & 326 & 7.5 & 101 & 0.00 & -3.44675 & 99.50480 \\
\hline 6 & 30 & 30 & 2 & 326 & 7.5 & 101 & 3.81 & -3.22308 & 99.35366 \\
\hline 7 & 30 & 30 & 2 & 326 & 7.5 & 101 & 1.02 & -2.99941 & 99.20255 \\
\hline 8 & 30 & 30 & 5.92 & 326 & 7.5 & 101 & 0.14 & -4.19186 & 100.33215 \\
\hline 9 & 30 & 30 & 5.92 & 326 & 7.5 & 101 & 3.25 & -3.96819 & 100.18078 \\
\hline 10 & 30 & 30 & 5.92 & 326 & 7.5 & 101 & 3.06 & -3.74452 & 100.02946 \\
\hline 11 & 30 & 30 & 5.92 & 326 & 7.5 & 101 & 3.01 & -3.52085 & 99.87819 \\
\hline 12 & 30 & 30 & 5.92 & 326 & 7.5 & 101 & 3.79 & -3.29718 & 99.72696 \\
\hline 13 & 30 & 30 & 5.92 & 326 & 7.5 & 101 & 4.96 & -3.07351 & 99.57577 \\
\hline 14 & 30 & 30 & 5.92 & 326 & 7.5 & 101 & 0.00 & -2.84983 & 99.42461 \\
\hline 15 & 30 & 30 & 9.83 & 326 & 12 & 101 & 0.00 & -4.04228 & 100.55451 \\
\hline 16 & 30 & 30 & 9.83 & 326 & 12 & 101 & 0.00 & -3.81861 & 100.40307 \\
\hline 17 & 30 & 30 & 9.83 & 326 & 12 & 101 & 0.00 & -3.59494 & 100.25170 \\
\hline 18 & 30 & 30 & 9.83 & 326 & 12 & 101 & 0.00 & -3.37127 & 100.10037 \\
\hline 19 & 30 & 30 & 9.83 & 326 & 12 & 101 & 3.34 & -3.14760 & 99.94908 \\
\hline 20 & 30 & 30 & 9.83 & 326 & 12 & 101 & 0.00 & -2.92393 & 99.79784 \\
\hline 21 & 30 & 30 & 9.83 & 326 & 12 & 101 & 0.42 & -2.70026 & 99.64665 \\
\hline 22 & 30 & 30 & 16.07 & 326 & 12 & 101 & 1.97 & -3.89471 & 100.77383 \\
\hline 23 & 30 & 30 & 16.07 & 326 & 12 & 101 & 0.00 & -3.67104 & 100.62234 \\
\hline 24 & 30 & 30 & 16.07 & 326 & 12 & 101 & 0.00 & -3.44737 & 100.47091 \\
\hline 25 & 30 & 30 & 16.07 & 326 & 12 & 101 & 0.12 & -3.22370 & 100.31953 \\
\hline 26 & 30 & 30 & 16.07 & 326 & 12 & 101 & 0.00 & -3.00003 & 100.16820 \\
\hline 27 & 30 & 30 & 16.07 & 326 & 12 & 101 & 0.00 & -2.77636 & 100.01691 \\
\hline 28 & 30 & 30 & 16.07 & 326 & 12 & 101 & 0.00 & -2.55268 & 99.86567 \\
\hline
\end{tabular}




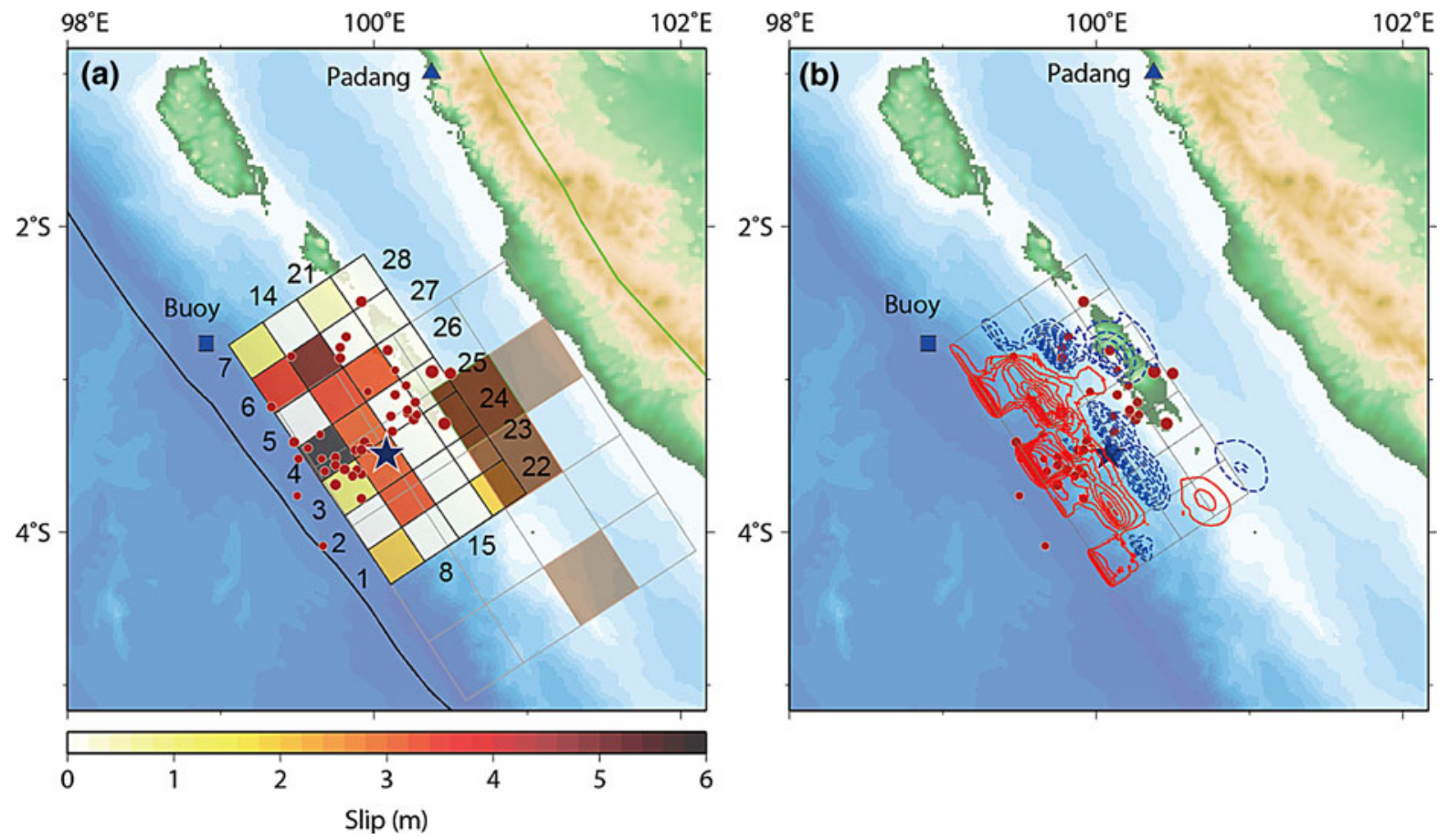

Figure 10

Slip distributions estimated by the inversion a and computed seafloor deformation $\mathbf{b}$. The subfault number (Table 2), the epicenter (blue star), aftershocks (red), and the slip distribution of the 2007 Bengkulu earthquake (FuJI and SATAKE 2008) are shown in a. Contour interval in (b) is $0.2 \mathrm{~m}$ for uplift (red) and $0.1 \mathrm{~m}$ for subsidence (dashed blue)

occurred on the shallower subfaults $(60 \mathrm{~km}$ width). Except at a few subfaults, the slips on deeper subfaults were mostly zero. Late first arrival of the tsunami at Padang prohibited large slip on the deep fault off North Pagai Island. This was in contrast to the 2007 Bengkulu earthquake, which had the most slip at the deeper part of the plate interface (FusI and SAtake 2008; Fig. 10a). The largest slip, $6.1 \mathrm{~m}$, was estimated on the shallowest subfault near the epicenter. The average slip on shallower subfaults was approximately $2 \mathrm{~m}$. The resultant seafloor deformation (Fig. 10b) showed that a small amount (up to a few tens of $\mathrm{cm}$ ) of subsidence was expected only on a part of North Pagai Island. The maximum subsidence recorded at GPS stations was approximately $4 \mathrm{~cm}$ on the west coat of South Pagai island (HiLl et al., 2012). The computed tsunami waveforms from this seafloor deformation reproduced the observed waveforms very well (Fig. 8). In particular, the two pulses recorded at the Mentawai buoy seemed to be from two large slip patches (subfaults 4 and 6) and lack of slip in between (subfault 5).
Slip on the shallow subfault ranged from 1 to $6 \mathrm{~m}$, while slip on the deep subfaults was smaller. The maximum computed slip of $6.1 \mathrm{~m}$ was somewhat smaller than that estimated from seismic wave analysis (4.5 to $9.6 \mathrm{~m}$; LAY et al., 2011; BILEK et al., 2011; NeWman et al., 2011) or from the GPS and tsunami modeling (9.7 m; HiLl et al., 2012), although the size of slip patches of the above analyses was smaller. The seismic moment was computed as $1.0 \times 10^{21} \mathrm{Nm}$, assuming the rigitidy of $3 \times 10^{10}$ $\mathrm{N} / \mathrm{m}^{2}$. The corresponding moment magnitude was $\mathrm{M}_{\mathrm{w}}=7.9$.

\subsection{Detailed Simulations Around Pagai Islands}

Nearshore tsunami heights on 9-arcsec $\left(9^{\prime \prime}\right)$ grids were calcualted using the linear shallow-water wave equations and the source model described in the previous section. On the east coast of the Pagai Islands, the computed nearshore tsunami heights were less than $2 \mathrm{~m}$. The computed heights on the west coasts varied from place to place, ranging from 


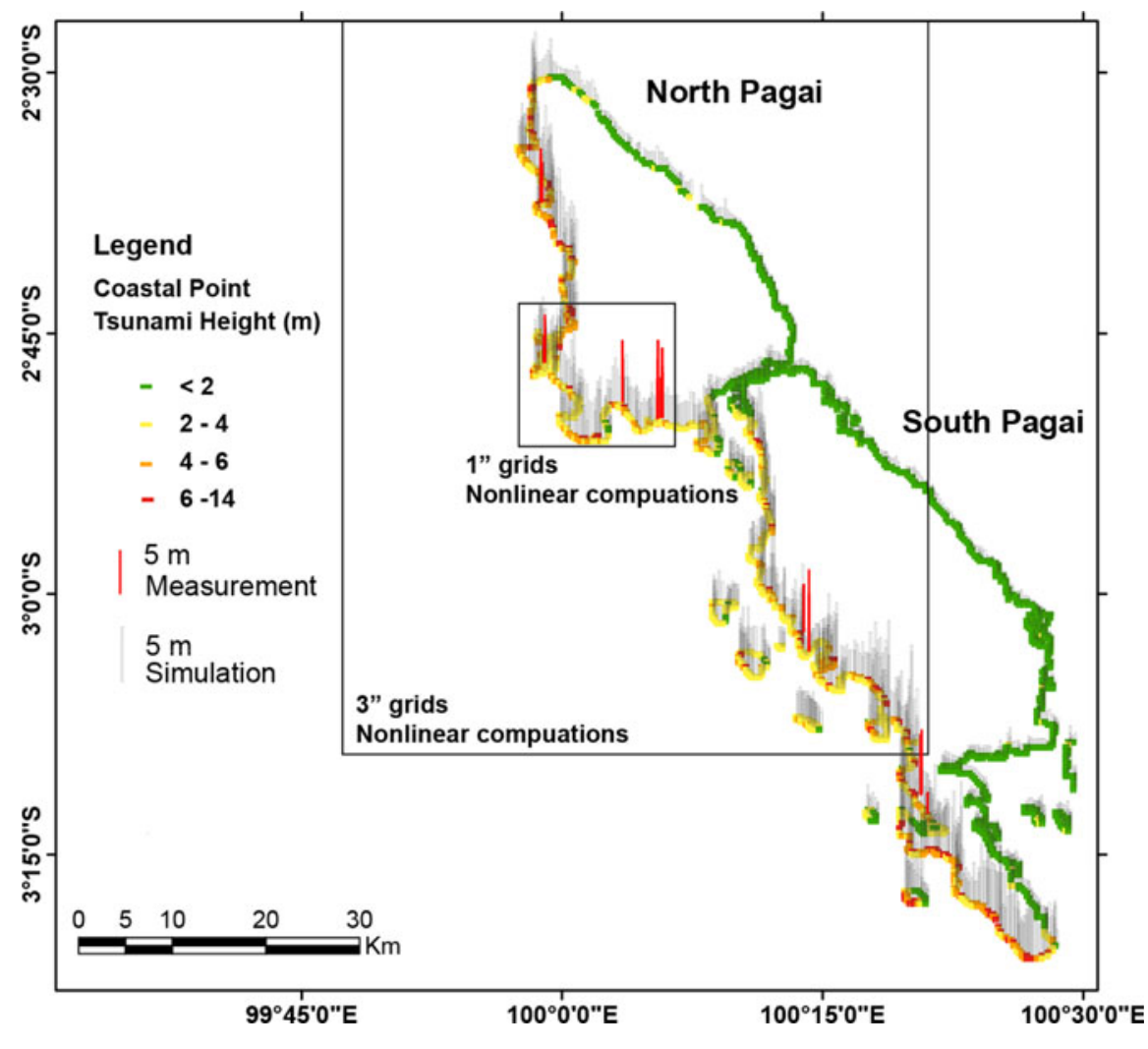

Figure 11

Computed coastal tsunami heights by using the fine-scale bathymetry $\left(9^{\prime \prime}\right)$ and linear equation. The gray bars and colors show the computed nearshore heights. The red bars show the measured heights. Areas for nested grids $\left(3^{\prime \prime}\right.$ and $\left.1^{\prime \prime}\right)$ with nonlinear computations with inundation are also shown

2 to $14 \mathrm{~m}$ (Fig. 11). In general, the computed heights were larger on the northern coast of North Pagai Island and the southern coast of South Pagai Island than on the coasts between, as can be seen in the color of coasts in the figure. Our computation showed a maxmimum nearshore tsunami height of $7.8 \mathrm{~m}$ around Sibigau Island, where the extreme run-up height of $>16 \mathrm{~m}$ was reported by HiLl et al., (2012).

Comparison of the measured tsunami heights with the computed nearshore heights within $500 \mathrm{~m}$ of the measurement points showed that they are similar at most locations. At Maonai, the computed heights ranged from $4.9-8.1 \mathrm{~m}$, while the measured heights ranged from 6.7-7.3 m. On North Pagai Island, the computed heights ranged from 2.8 to $6.5 \mathrm{~m}$ at Tumalei (measured heights are 4.0-6.1 m), from 2.2 to $3.8 \mathrm{~m}$ at Macaronis resort (measured heights are $2.9-5.4 \mathrm{~m}$ ), from $2.0-4.0 \mathrm{~m}$ at Muntei Barubaru (measured heights are $4.6-5.7 \mathrm{~m}$ in the village and
3.9-8.8 $\mathrm{m}$ on the western side), and from 3.0-6.8 $\mathrm{m}$ in Sabeu Gunggung (measured heights are 4.3$7.0 \mathrm{~m}$ ). An exception is at Asahan where the computed heights ranging from 1.8 to $3.1 \mathrm{~m}$ were much smaller than the measured heights ranging from 6.4 to $9.3 \mathrm{~m}$.

Nonlinear computations, including inundation on land, were carried out on finer $\left(3^{\prime \prime}\right.$ and $\left.1^{\prime \prime}\right)$ grids. The coastal and inundation heights on the finest grids $\left(1^{\prime \prime}\right)$ were shown in Fig. 12 with enlarged maps at Muntei Barubaru, Sabeu Gunggung, and Macaroni Resort. Comparison of the computed inundation distance and heights with the measurements showed that the computed results are smaller than the measurements. A comparison of coastal heights from linear to nonlinear computations indicated that the nonlinear computations produced smaller coastal heights than the linear computations by a factor ranging from 1.3 to 2.2. Nonlinear effects include advection terms and 


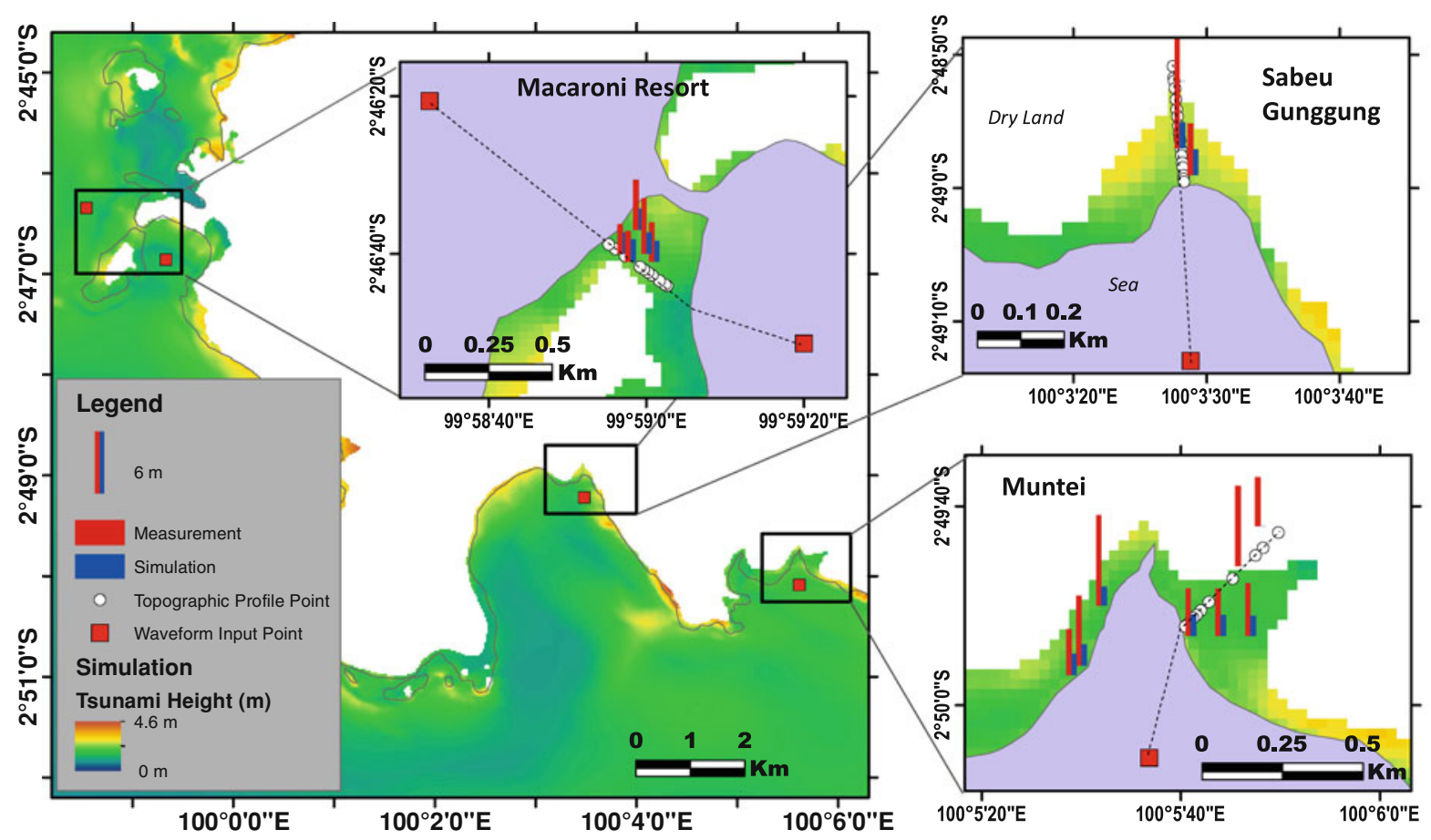

Figure 12

Computed tsunami inundation areas (color) and comparisons of measured and computed tsunami heights (red and blue bars, respectively) at Muntei Barubaru, Sabeu Gunggung, and Macaroni Resort on the finest grid (1"). One-dimensional computations (Sect. 3.6) are made along the dashed lines, using the input waveforms computed at offshore points shown by red squares. White circles show the topographic profiles based on our field measurements (Fig. 5)

bottom friction, and both depend on bathymetry. As described in Sect. 3.2, our bathymetry data were not accurate enough for $3^{\prime \prime}$ or $1^{\prime \prime}$ grids, particularly the arbitrary correction applied to topography data (7 m elevation reduced from the SRTM data). In order to examine the effects of topographic data, we carried out one-dimensional inundation computation using topographic profiles measured during the field survey.

\subsection{One-dimensional Inundation Computations}

The tsunami run-up heights along the measured topography profiles were computed and compared with the measured tsunami heights (Fig. 5). The waveforms calculated at offshore points of Sabeu Gunggung, Muntei, and Macaroni Resort on a $1^{\prime \prime}$ grid with linear and nonlinear computations, at Tumalei on a $3^{\prime \prime}$ grid with linear and nonlinear computations, and at Maonai on a $9^{\prime \prime}$ grid with linear computations were used as input for the 1D computation. When the linear input waveforms were used, the computed tsunami inundation heights were mostly similar or larger than the measured heights projected on the profile, except at Sabeu Gunggung. Considering that not all the measured points were located on the profile, the agreement was rather satisfactory. When the nonlinear input waveforms were used, the computed inundation heights were somewhat smaller than the measured heights. The discrepancy came from the different amplitudes of input waveforms. The amplitudes on the $1^{\prime \prime}$ grid were smaller than those on the $9^{\prime \prime}$ grid by a factor of 1-1.7; the nonlinear computation produced smaller amplitudes than the linear computation.

\section{Conclusions}

1. Tsunami heights were measured at eight locations on the west coast of North and South Pagai Islands. Thirty-eight measurements ranged from 2.5 to $9.3 \mathrm{~m}$, but mostly $4-7 \mathrm{~m}$. The tsunami inundation distance was more than $300 \mathrm{~m}$ at three 
locations. Our survey was made within 2 weeks of the earthquake, when sea conditions were very rough, making land access difficult. Later surveys (KERPEN et al., 2011; Hill et al., 2012) covered larger areas and reported more extreme tsunami heights.

2. This earthquake was a tsunami earthquake, one that produces weak ground shaking but large tsunamis. Residents reported that the ground shaking was weaker than during the 2007 Bengkulu or the 2009 Padang earthquake.

3. The official tsunami warning from BMKG reached the Mentawai regency office, but did not reach coastal communities because of the lack of communication infrastructure. However, some coastal residents were watching TV and saw running text of a tsunami warning 5-18 min after the earthquake, according to BMKG (2010).

4. Inversion of tsunami waveforms indicated the slip was larger at offshore subfaults, with a maximum of $6.1 \mathrm{~m}$. In particular, the nearby surface GPS buoy recorded two pulses of tsunami waves, probably from two large slip regions at shallower subfaults.

5. The nearshore tsunami heights computed from the above source model using the fine-scale bathymetry $\left(9^{\prime \prime}\right)$ and linear equations were roughly similar to our measured heights. Tsunami inundation heights computed on a $1^{\prime \prime}$ grid using nonlinear equations were smaller than the measured heights, probably because of inaccurate bathymetry and topography. The one-dimensional computations using measured profiles reduced the discrepancy.

\section{Acknowledgments}

This survey was made as a part of the SATREPS "Multi-disciplinary natural hazard reduction from earthquakes and volcanoes in Indonesia" project supported by the JST (Japan Science and Technology
Agency) and JICA (Japan International Cooperation Agency), as well as RISTEK and LIPI. Among the authors, KS, YN, PSP, HS, and EY conducted the survey. We thank Pariatmono, Mulyo Harris Pradono, Atsushi Koresawa, and Megumi Sugimoto, who also joined the survey to study the reactions of residents. We thank Jody Bourgeois for reading and commenting on the results of the field survey. The tsunami waveform analysis and simulations were conducted by KS, ARG, HS, TF, HL, and YT. In particular, YF took the lead in tsunami waveform inversion, HS in detailed simulation, and ARG in one-dimensional computation. We respect and appreciate the efforts of the operators of the costal tide gauge stations, DART and GPS buoy stations. The buoy data were provided to us by Wahyu Pandoe of BPPT and Tilo Schoene at GFZ. We also thank Jose Borrero, two anonymous reviewers, and Herman Fritz for their comments on the final manuscript.

Open Access This article is distributed under the terms of the Creative Commons Attribution License which permits any use, distribution, and reproduction in any medium, provided the original author(s) and the source are credited.

\section{REFERENCES}

Badan Meteorologi Klimatologi dan Geofisika (2010), Laporan Gempabumi Mentawai, 25 Oktober 2010, 18 pp.

Bilek, S.L., Engdahl, E.R., DeShon, E.R., and HariRi, M.E. (2011), The 25 October 2010 Sumatra tsunami earthquake: Slip in a slow patch, Geophys. Res. Lett., 38, L14306, doi: 10.1029/2011GL047864.

Borrero, J.C., Weiss, R., Okal, E. A., Hidayat, R., Suranto, Arcas, D., and Titov, V. (2009), The tsunami of 2007 September 12, Bengkulu province, Sumatra, Indonesia: post-tsunami field survey and numerical modeling, Geophys. J. Int., 178, 180-194.

Fritz, H.M., Kongko, W., Moore, A., McAdoo, B., Goff, J., Harbitz, C., Uslu, B., Kalligeris, N., Suteja, D., Kalsum, K., Titov, V., Gusman, A., Latief, H., Santoso, E., Sujoko, S., Duulkarnaen, D., Sunendar, H., and Synolakis, C.E. (2007), Extreme runup from the 17 July 2006 Java tsunami, Geophys. Res. Lett., 34, L12602, doi:10.1029/2007GL029404.

FujII, Y., and SATAKE, K. (2006), Source of the July 2006 West Java tsunami estimated from tide gauge records, Geophys. Res. Lett., 33, L24317, doi:10.1029/2006GL028049.

FujII, Y., and SATAKE, K. (2007), Tsunami source of the 2004 Sumatra-Andaman Earthquake inferred from tide gauge and satellite data, Bull. Seism. Soc. Am., 97, S192-S207.

FujI, Y., and SATAKE, K. (2008), Tsunami waveform inversion of the 2007 Bengkulu, southern Sumatra, earthquake, Earth, Planets Space, 60, 993-998. 
Gusman, A. R., Tanioka, Y., and Takahashi, T. (2012), Numerical experiment and a case study of sediment transport simulation of the 2004 Indian Ocean tsunami in Lhok Nga, Banda Aceh, Indonesia, Earth Planets Space, (in press).

Hill, E.M., Borrero, J.C., Huang, Z., Qiu, Q., Banerjee, P., Natawidjaja, D.H., Elosegui, P., Fritz, H.M., Suwargadi, B.W., Pranantyo, I.R., Li, L.-L., MacPherson, K.A., Skanavis, V., Synolakis, C.E., and SieH, K. (2012), The 2010 Mw 7.8 Mentawai earthquake: very shallow source of a rare tsunami earthquake determined from tsunami field survey and near-field GPS data, J. Geophys. Res. 117, B06402, doi:10.1029/2012 JB009159.

Kerpen, N.B., Kongko, W., Kramer, K.D.D., Goseberg, N., and Schlurmann, T. (2011), International post-tsunami survey related to the October 25th, 2010 Mentawai tsunami, GFZ German Research Centre for Geoscience, Report -Nr. 716, 31 pp.

Lay, T., Ammon, C.J., Kanamori, H., Yamazaki, Y., Cheung, K.F., and Hutкo, A.R. (2011), The 25 October 2010 Mentawai tsunami earthquake $\left(M_{w}\right.$ 7.8) and the tsunami hazard presented by shallow megathrust ruptures, Geophys. Res. Lett., 38, L06302, doi:10.1029/2010GL046552.

Natawidjaja, D.H., Sieh, K., Chlieh, M., Galetzka, J., Suwargadi, B.W., Cheng, H., Edwards, R.L., Avouac, J-P., and Ward, S.N. (2006), Source parameters of the great Sumatran megathrust earthquakes of 1797 and 1833 inferred from coral microatolls, J. Geophys. Res., 111. B06403, doi:10.129/2055JB004025.

Newman, A.V., Hayes, G., Wei, Y., and Convers, J. (2011), The 25 October 2010 Mentawai tsunami earthquake, from real-time discriminants, finite-fault rupture, and tsunami excitation, Geophys. Res. Lett., 38, L05302, doi:10.1029/2010GL046498.

ОкADA, Y. (1985), Surface deformation due to shear and tensile faults in a half-space, Bull. Seism. Soc. Am., 75, 1135-1154.

Putra, P. S., Nishimura, Y., and Yulianto, E. (2012), Sedimentary features of tsunami deposits in carbonate-dominated beach environments: a case study from the 25 October 2010 Mentawai Tsunami, Pure Appl. Geophys. (in press).

SAHAL, A. and Morin, J. (2012). Effects of the October 25, 2010, Mentawai tsunami in La Réunion Island (France): observations and crisis management, Nat. Hazards, 62, 1125-1136, doi: 10.1007/s11069-012-0136-2.

SAtAKE, K. (1995), Linear and nonlinear computations of the 1992 Nicaragua earthquake tsunami, Pure Appl. Geophys., 144, 455-470.

Sieh, K., Natawidjaja, D.H., Meltzner, A.J., Shen, C.-C., Cheng, H., Li, K.-S., Suwargadi, B.W., Galetzka, J., Philibosian, B., and EDWARDS, R.L. (2008), Earthquake supercycles inferred from sea-level changes recorded in the corals of West Sumatra, Science, 322, 1674-1678.

Singh, S.C., Hananto, N., Mukti, M., Permana, H., Duajadihardja, Y., and Harjono, H. (2011), Seismic images of the megathrust rupture during the 25th October 2010 Pagai earthquake, SW Sumatra: frontal rupture and large tsunami, Geophys. Res. Lett., 38, L16313. doi:10.1029/2011GL048935.

TANioka, Y. and Satake, K. (1996), Tsunami generation by horizontal displacement of ocean bottom, Geophys. Res. Lett., 23, 861-864. 